Chapter 3 in RECONCEPTUALIZING GLOBAL FINANCE (Ross Buckley, Doug Arner \& Emilios

Avgouleas eds. Cambridge University Press, forthcoming 2014)

Please do not quote or cite without permission from the author.

\title{
UNDERSTANDING THE GLOBAL IN GLOBAL FINANCE AND REGULATION
}

\author{
Lawrence G. Baxter.
}

$\begin{array}{lr}\text { From "International" to "Global" } & 4 \\ \text { Enter the Sovereign } & 4 \\ \text { Interconnectedness and Liberalization } & 5 \\ \text { Global Financial Regulation: From Coordination to Harmonization to Unification? } & 6 \\ \text { The Basel Committee } & 6 \\ \text { G20 and Financial Stability Board } & 7 \\ \text { Transnational Regulatory Networks and "Soft Law" } & 7 \\ \text { Trade Liberalization and the Free Flow of Finance } & 9 \\ \text { Business Globalization: Enterprises That Will Not Be Easily Governed } & 10 \\ \text { Global Operational Integration } & 10 \\ \text { Global Technology } & 11 \\ \text { Global Business and Finance } & 12 \\ \text { Consequences for Global Governance } & 15 \\ \text { National Concerns-An Added Dimension of Complexity } & 15 \\ \text { Balkanization } & 15 \\ \text { Feeding the Global Maw } & 17 \\ \text { Global Autonomy } & 18 \\ \text { Financial Center Competition } & 19 \\ \text { New Tentacles of Sovereign Power } & 19 \\ \text { Banks Versus the State } & 20 \\ \text { International Solutions? } & 22 \\ \text { Conclusion } & 22\end{array}$

"Global" is an evocative adjective that generates, alternately, excitement and despair. ${ }^{1}$ It comes into vogue every few decades, the recent past being no exception. The latest cycle of "globalization" reached its apogee in 2008, evolving through the three-decade period from about 1980 to 2010 and roughly tracking the great trade breakthroughs of the World Trade Organization (WTO), ${ }^{2}$ North American Free Trade Agreement (NAFTA), ${ }^{3}$ etc., until the near collapse of the Eurozone in the wake of the Global Financial Crisis (GFC). ${ }^{4}$ As Niall Ferguson warned so presciently in 2005 we have seen such eras of optimism before. ${ }^{5}$ Yet, the cyclical nature of globalization notwithstanding, in many ways the "global" dimension is more real

\footnotetext{
- William B. McGuire Professor of the Practice of Law, Duke Law School.

${ }^{1}$ ECONOMIST, When did globalisation start?, Sep. 23, 2013, at

http://www.economist.com/blogs/freeexchange/2013/09/economic-history-1/.

${ }^{2}$ See http://www.wto.org/index.htm.

${ }^{3}$ See https://www.nafta-sec-alena.org/Default.aspx?tabid=97\&language=en-US.

${ }^{4}$ Histories and analyses of the GFC already abound. See, e.g., JohAn A. LybeCK, A Global History of THE FINANCIAL CRASH OF 2007-10 (2011).

${ }^{5}$ Niall Ferguson's Sinking Globalization, For. AfFAIRS (Mar./Apr. 2005), available at http://www.foreignaffairs.com/articles/60622/niall-ferguson/sinking-globalization.
} 
and present than ever, as manufacturing, technology, transportation and the digital integration of economies has made the fortunes of formerly distant places very proximate to all of us. ${ }^{6}$

In certain respects, financial systems have encountered "the end of geography."7 From the perspective of many large financial firms, globalization has indeed become a phenomenon distinct, in important ways, from other terms that are frequently used interchangeably with "global," such as "international," "multinational" and "trans-border."

Unsurprisingly, "global finance," the subject of this book, has become a perfectly comfortable and appropriate term. Too comfortable-because we seldom pause to dwell on what "global" really means to finance and what are some of its more far-reaching implications. This chapter will explore the "global" view of modern financial firms, and how such a view drives the need for global governance and regulation while at the same time undermining the realization of adequate structures to meet this demand. At first glance, it might appear that our global regulatory institutions are indeed keeping up with the emergence of truly global finance. Deeper consideration, however, reveals a much more problematic panorama.

The development of global business and finance promoted the creation of transnational governance organizations such as the G20, ${ }^{8}$ the Bank for International Settlements (BIS), ${ }^{9}$ Basel Committee on Banking Supervision (BCBS), ${ }^{10}$ and Financial Stability Board (FSB), ${ }^{11}$ and has extended into financial supervision the activities of international financial institutions (IFIs) such as the World Bank for Reconstruction

\footnotetext{
${ }^{6}$ The view expressed here regarding cycles of globalization is possibly too Western-centric. A widely disseminated report by Standard Chartered Bank's Global Research Group would disagree with the opinion expressed earlier that we have reached the end of another cycle of globalization. STANDARD CHARTERED BANK GLOBAL RESEARCH, THE SUPERCYCLE REPORT (2010), available at https://research.standardchartered.com/configuration/ROW\%20Documents/The\%20SuperCycle\%20Report_14_11_10_16_32.pdf. The report views the new "super-cycle" of globalization as really having begun in 2000 and likely to last until 2030, and it anticipates a huge financial deepening in Asia and other emerging economies.

${ }^{7}$ RichaRd O’BRIEn, GLOBAL FinANCIAL InTEGRATION: THE END OF GEOGRAPHy (1991).

${ }^{8}$ https://www.g20.org.

${ }^{9}$ http://www.bis.org/index.htm.

$10 \mathrm{http}: / /$ www.bis.org/bcbs/index.htm.

${ }^{11}$ https://www.financialstabilityboard.org.
} 
and Development (World Bank) ${ }^{12}$ and International Monetary Fund (IMF). ${ }^{13}$ Yet at the same time, the rising power of global financial institutions has fostered national reactions against both globalization and global governance, a Balkanization that perpetuates, perhaps even accentuates, rather than diminishes the "global paradox" once thought resolved by liberal international relations theorists. ${ }^{14}$ In an era when a "global" solution to modern finance is most needed, it seems further away than ever. The primary reason, it will be argued, lies in the nature of modern global finance itself.

These developments have progressed amidst, have influenced, and have been influenced by, a much larger change in the nature of global relationships. Having evolved from a system of custom- and natural law-based norms into the Westphalian regime characterized by the mutual interactions of sovereign states, ${ }^{15}$ international ("global") financial regulation is now reforming around a world ordered by what Philip Bobbitt has called a "society of market states."16 In this global society, globalized financial institutions have come to occupy a central role in public ordering, and the emerging regime of financial regulation is assuming very different forms from those familiar in traditional international law. This is a world in which treaties are no longer so dominant, and non-governmental organizations, individuals and groups have significant standing. It is a world in which, along with business ${ }^{17}$ and state competition, ${ }^{18}$ we are seeing a mix of multipolar market power,

$12 \mathrm{http}: / /$ www.worldbank.org.

$13 \mathrm{http://www.imf.org/external/index.htm.}$

14 See further the discussion infra text accompanying notes 35-37.

${ }^{15} \mathrm{On}$ the rise and fall of the Westphalian regime of state sovereignty and controversies surrounding whether the state system is in decline, e.g. HEdley Bull, The ANARCHICAl Society (4 ed. 2012); PhiliP BobBitT, The SHIEld of ACHILles: WAR, PeACE, AND the COURSE OF History (2002) ch. 7; David Held, The Changing Structure of International Law, THE GLOBAL TRANSFORMATIONS WEBSITE, available at http://www.polity.co.uk/global/pdf/GTReader2eHeld.pdf (last visited Nov. 5, 2012); William Twining, A Post-Westphalian Conception of Law, 37 L. \& Soc. REv. 199 (2003).

16 BoBвiтT, supra note 15, ch. 10.

17 One recent business mantra, related to game theoretic applications, is the concept of "co-opetition," a strategy by which businesses can learn to compete and cooperate with other businesses in order to extract maximum potential value from the marketplace. See, e.g., AdAM M. BrandEnBURGER \& BARRY J. NALEBuFF, Co-OPETITION (1996).

${ }^{18}$ A particularly insightful recent analysis of the adversarial/cooperative relations between the United States and China is NoAh Feldman, Cool War: The Future of Global Competition (2013). One can see such "conflicted" and strained relationships in many areas of financial regulation. See, eg., 
collaboration among states and financial firms, competition and conflict. This complex ordering (and disordering) is likely to shape the possibilities that lie ahead for global financial activity and its regulation.

\section{From "International" to "Global"}

Banking activities have always tended to follow the patterns of trade across large geographies, whether such patterns crossed political boundaries or not. The Knights Templar, perhaps the first great bankers to the world, were able to provide finance without borders in a world before sovereign nations. The Medicis and other great Italian dynasties did the same. To such bankers the term "global" might have been puzzling for its irrelevance as a restriction to their business: their world simply was global, at least to the extent that the known world was all that mattered.

\section{Enter the Sovereign}

The rise of the nation state, of sovereignty and sovereigns (the bankers' biggest clients), introduced new dimensions to bank activities and their regulation: in particular the concepts of "international," "multi-national" and "transnational." Different laws and restrictions mattered as one crossed sovereign boundaries; these constraints really mattered to the extent that money and banking lie so close to the breasts of sovereigns.

In turn, it became important to know whether a financial transaction was "domestic" or crossed jurisdictional boundaries. For financial companies, corporate structure and accountability became important because the legal forms of their operating entities were the product of the laws and regulations of the distinct, sovereign nations within which they operated.

For centuries in the era of the sovereign states, banks and other finance companies simply accommodated the jurisdictional boundaries by observing national law (where they were allowed by host countries to enter from abroad), taking advantage where this was useful of differences in the content of domestic

the sanctions applied by US regulators to foreign banking organizations and the reactions by governments to the US, discussed further, infra at notes 81-86. 
laws (regulatory arbitrage), or interacting at arms length with correspondents where this was necessary to overcome jurisdictional restrictions. Unlike the systems governing shipping, war and international relations, there was no significant lex mercatoria for banking regulation, no customary international law and no significant international treaties. International banking law was best analogized to a system of "bumper cars" in which the legal impact and constraints upon cross-border financial transactions depended largely on mutual and ad hoc agreements between pairs or groups of countries. ${ }^{19}$

Interconnectedness and Liberalization

Two major developments in globalization precipitated the evolution beyond international finance and toward global finance. The first flowed from the demise of Bretton Woods and the end of fixed exchange rates. ${ }^{20}$ This introduced a substantial new element of risk into cross-border banking, the fluctuation and volatility of exchange rates that, because of the interconnectedness of currency counterparties, quickly demonstrated the dependency of financial institutions across borders. Bankhaus Herstatt triggered a new awareness of the limitations of the bumper cars framework. ${ }^{21}$

The second was the facilitation of much greater cross border financial activity, precipitated by various rounds of financial liberalization, ranging from the negotiation of the Financial Services Annex of the World Trade Organization ${ }^{22}$ to the

\footnotetext{
${ }^{19}$ Michael Malloy, Bumper cars: themes of convergence in international regulation, 60 FORDHAM L. REV 23 (1992).

${ }^{20}$ See, e.g., Nixon and the End of the Bretton Woods System, 1971-1973 (US Dept. of State, Office of the Historian), http://history.state.gov/milestones/1969-1976/nixon-shock.

21 The failure of Bankhaus Herstatt, following almost immediately upon the breakdown of the Bretton Woods system and the world's new exposure to floating exchange rates, led directly to the creation of the Basel Committee on Banking Supervision. See http://www.bis.org/bcbs/history.htm. On the failure and its impact, see, e.g., The long, dark shadow of Herstatt, EconOMIST, Apr. 12, 2001, http://www.economist.com/node/574236; Gergana Koleva, 'Icon of Systemic Risk' Haunts Industry Decades After Demise, Am. BANKER, Jun 23, 2011, http://www.americanbanker.com/bankthink/bankhaus-herstatt-icon-of-systemic-risk-10393121.html. (The AMERICAN BANKER also republished its historic front page reporting the failure. See http://www.americanbanker.com/175/cologne-bank-shut-exchange-losses-cited-1039304-1.html.

${ }^{22}$ See the Financial Services Annex to the General Agreement on Trade in Services, http://www.wto.org/english/tratop_e/serv_e/10-anfin_e.htm.
} 
financial sections of regional treaties such as NAFTA. ${ }^{23}$ Banks, mainly Western and well endowed with capital, searched for the richer returns offered by new development. They were able, in many cases for the first time, and were encouraged, to enter underdeveloped markets. The great enterprise of global "financial deepening" had begun in earnest. ${ }^{24}$ Finance had become truly global, rushing to meet the vacuums presented by new markets wherever they were, facilitated through new techniques of debt and equity exchange financing, ${ }^{25}$ and operating irrespective of national boundaries. ${ }^{26}$

\section{Global Financial Regulation: From Coordination to Harmonization to Unification?}

The Basel Committee

The failure of Bankhaus Herstatt in $1974^{27}$ highlighted for central bankers across the world the perils of interconnectivity. Regulators seized the small German bank at the end of the workday in Germany yet, because of the time difference, New York counterparty banks were caught in the middle of the East Coast workday by the default. The Bank for International Settlements was prompted to create the primary international fulcrum for international banking regulation, namely the Basel Committee on Bank Supervision (BCBS). ${ }^{28}$ From the BCBS has since flowed a long series of increasingly detailed supervisory principles, culminating in the Basel III capital regime, ${ }^{29}$ that are designed to develop and maintain as close coordination among national financial regulators as possible.

\footnotetext{
23 See NAFTA ch. 14 "Financial Services," at https://www.nafta-secalena.org/Default.aspx?tabid=97\&ctl=SectionView\&mid=1588\&sid=827a9405-deb8-4285-bf07790c6550c6f5\&language $=$ en-US.

24 On which, see, e.g., Nobuhiro Kiyotake \& John Moore, Financial Deepening, 3(2-3) J. Eur. Econ. Ass'N 701 (2005).

25 See Ross P. BuCKley, DebT-For-Development Exchanges: History And New ApPlicAtions (2011).

${ }^{26}$ For general reviews of this process of global banking growth and its relationship to financial liberalization, see, e.g., Alfred Slager, THE InTERnATIONALizATION OF BANKS ch. 1 (2006); Douglas W. ARnER, FinANCIAL STABILITY, ECONOMIC GROWTH AND THE ROLE OF LAW (2007).

27 See text supra at note 21.

$28 \mathrm{http}: / /$ www.bis.org/bcbs/index.htm.

${ }^{29}$ For the details and Basel III texts, see http://www.bis.org/bcbs/basel3.htm.
} 


\section{G20 and Financial Stability Board}

Associated with the work of the BCBS has been that of a number of other committees and forums to develop standards and a certain degree of consensus on the principles of bank supervision, treatment of offshore financial centers, international money laundering, accounting standards and the like. The World Bank and IMF have established a peer review system to try to lift the standards observed by all nations. ${ }^{30}$ Perhaps the most far-reaching efforts beyond those of the BCBS itself have been those driven by the Group of Twenty (G20) ${ }^{31}$ in reaction to the GFC, and the Financial Stability Board ${ }^{32}$ (upgraded by the G20 from the former Financial Stability Forum) to address the dangers posed by so-called systemically important financial institutions and banks. The FSB has become, in effect, the key coordinator for implementation of the G20 policy agenda and development of what has been called the "New International Financial Architecture."33

\section{Transnational Regulatory Networks and "Soft Law"}

Various attempts have been made to provide an underlying theory concerning the legal status and legitimacy of these largely committee-driven, and mostly nontreaty-based developments. ${ }^{34}$ One explanation is that promoted by liberal international relations authorities such as Robert Keohane and Ann Marie Slaughter, namely the theory of "transnational regulatory networks" (TRNs). Anne-Marie Slaughter, for example, developed the concept of "transnational regulatory networks" (TRNs) to describe this mechanism as a hallmark of a "new world

\footnotetext{
${ }^{30}$ On the IMF/World Bank Financial Sector Assessment Program (FSAP), see http://www.imf.org/external/np/fsap/fssa.aspx (IMF); and http://web.worldbank.org/WBSITE/EXTERNAL/TOPICS/EXTFINANCIALSECTOR/0,,contentMDK:22 142161 menuPK:6459396 pagePK:210058 piPK:210062 theSitePK:282885,00.html. Other organizations such as the BCBS and FSB have also instituted peer assessment programs.

31 See the description of the G20 and its mission by the G20 Information Center, http://www.g20.utoronto.ca/g20whatisit.html.

$32 \mathrm{https}$ ///www.financialstabilityboard.org.

${ }_{33}$ See Joseph J. Norton, Banking Law Reform and Users-Consumers in Developing Economies: Creating an Accessible and Equitable from the "Excluded," 42 Tex. Int'l L. J. 789 at 792 n. 7 (and the sources there cited).

${ }^{34}$ The work of the World Bank, IMF and the European Union is of course treaty based.
} 
order."35 TRNs are celebrated as a means of resolving the "global paradox," in terms of which “[w]e need more government on a global or regional scale, but we don't want the centralization of decision-making power and coercive authority so far from the people actually to be governed."36

TRNs reconcile these conflicting demands by enabling national regulatory representatives (who are theoretically accountable to more directly elected domestic superiors) to collaborate in the development of a moderately consistent set of global principles upon which modern finance can be based. With each nation applying its own enforcement mechanisms, international financial regulation acquires a kind of transnational reality. Of course, whether these explanations satisfy the basic demands of democracy or, as Ross Buckley puts it elsewhere in this volume, "societal consent," is another matter. ${ }^{37}$

This emergence of international financial regulatory standards is also accommodated within more orthodox public international law doctrine under the epithet of "soft law."38 In common with many other areas of international principle not buttressed by formal treaties, such international regulation has a very real presence in the formal enforcement mechanisms of domestic jurisdictions. Indeed,

\footnotetext{
35 ANNe-MARIE Slaughter, A New World ORder (2004). see also Kal Raustiala, The architecture of international cooperation: trans- governmental networks and the future of international law, (2002) 43 VIRGINIA JOURNAL OF INTERNATIONAL LAW 1; David Zaring, International law by other means: the twilight existence of international financial regulatory organizations, (1998) 33 TEXAS INTERNATIONAL LAW JOURNAL 281; Pierre-Hugues Verdier, Transnational regulatory networks and their limits, (2009) 34 YALE JOURNAL INTERNATIONAL LAW 113. TRNs have been long in their evolution: see ALAN BoYLE AND Christine Chinkin, The MAKING OF InTERnATIONAL LAW (2007) at 51. See also Lawrence G. Baxter, The Internationalisation of law - the 'complex' case of bank regulation, in THE INTERNATIONALISATION OF LAW: LeGislating, Decision-Making, PRACTICE AND EduCATION 3 at 18-19 (Mary Hiscock \& William van Caenegem eds. 2010); Diane Stone, Transfer agents and global networks in the 'transnationalization' of policy, 11:3 J. EUR. PUB. POL'Y 545 (2004).

36 SLAUGHTER, supra note 35 , at 8.

${ }^{37}$ Ross Buckley, The Changing Nature of Banking and Why it Matters, ch. 1 supra.

38 Emilios Avgouleas, GovernanCE of Global FinANCial MARKETS: THE LAW, THE ECONOMICS, THE POLITICS ch. 5 (2012); Chris Brummer, Soft LaW AND the Global FinanCial System: Rule MaKing In the $21^{\text {st }}$ CEnTURY (2012); Jean Galbraith \& David Zaring, Soft Law as Foreign Relations Law, 99 CoRn. L. Rev. 735 (2014). And see further Douglas Arner \& Michael Taylor, FSB and Hardening of Soft Law, infra ch. 4.
} 
David Zaring has plausibly argued that global financial regulation is as real as many more traditional and better-recognized areas of public international law. ${ }^{39}$

Trade Liberalization and the Free Flow of Finance

Treaties promoting financial liberalization and access by foreign banks to new markets have also assumed and encouraged graduated reciprocity between signatories. While the underlying principle of reciprocity has been implicit to some extent in the financial annexes to regional trade treaties and common application of the most favored nation (MFN) principle, ${ }^{40}$ the most prominent and far reaching examples being embraced within the EU single banking passport and, more recently, the European Banking Union. ${ }^{41}$ This trend has tended to encourage the adoption of the principle of "mutual recognition" between host jurisdictions of the supervisory primacy by "headquarters" regulators.

In the view of some, these developments seem to presage the real possibility that the financial regulatory regimes of various nations might actually be harmonized, if not actually rendered uniform. Such aspirations matched reasonably the emerging reality of modern banking, namely that it was being conducted with less and less regard to geographic boundaries. ${ }^{42}$

With such rapid progress occurring within the span of only three or four decades, it is no surprise that some might have believed that this TRN or soft law would harden into something close to a more formal and meaningful regime of global financial regulation. Such a view might even have found support in academic analyses of trends in international relations, among which was the declaration by one such expert that a "World State" was "inevitable."43 Indeed, a progression from coordination to harmonization and even to actual unification seemed not only

\footnotetext{
39 David Zaring, Legal Obligation in International Law and International Finance, 47 CORNELL J. INT'L L. _ (forthcoming 2015). Professor Zaring elaborates more fully in this volume on the network of networks that now comprise the international financial regulatory regime. See David Zaring, Financial Regulation's Overlooked Networks, infra ch. 5.

${ }^{40}$ See generally, e.g., Brummer, supra note 38, at 52-57; David Zaring, Finding Legal Principle in Global Financial Regulation, 52 VA. J. INT'L L. 683, at 706-07 (2012).

${ }^{41} \mathrm{http}$ ///ec.europa.eu/internal_market/finances/banking-union/index_en.htm.

${ }^{42}$ This latter trend will be explored further below.

${ }^{43}$ Alexander Wendt, Why a World State is Inevitable, 9 EUR. J. INT'L REL. 491 (2003).
} 
possible but, as the following section will argue, even essential if modern finance is to be subject to any efficient and reliable regulation at all.

\section{Business Globalization: Enterprises That Will Not Be Easily Governed}

Globalization has, however, proved to be a multi-faceted concept, at least as it is manifested in finance. One of the most problematic features of true globalization has become starkly apparent. Perhaps more than in any other industry, financial services run along nearly instantaneous digital tracks. The impact of events in one quarter of the globe will be nearly instantly felt everywhere, never more dramatically illustrated than with the GFC. The reverberations from the collapse of Lehman Brothers affected every major financial center. ${ }^{44}$ The interconnectednesseven the perceived interconnectedness-of Lehman counterparties and their counterparties froze the global economy and precipitated an already teetering financial system into full blown crisis. ${ }^{45}$

These events drove the G20 nations resolve in declaring a commitment to concerted action in order to recover from the GFC and prevent future systemic meltdowns. ${ }^{46}$ Major reforms were also initiated in the United States, United Kingdom, Europe and elsewhere. Given this impetus, one might have expected far reaching and collaborative actions by all the world's leading economies, even leading ultimately to a much more coherent and perhaps even uniform regime of international financial regulation. Banking operations have themselves become more global than ever.

Global Operational Integration

\footnotetext{
${ }^{44}$ AvgoulEAS, supra note 38, 76. For the full story on Lehman's collapse, see LAWRENCE G. MCDoNALD \& Patrick Robinson, A Colossal Failure of Common SEnSE" The Inside STORY of THE Collapse of Lehman BROTHERS (2009).

45 One need not enter into the (largely pointless) debate whether the failure of Lehman Brothers on September 15, 2008, was the real or even the proximate cause of the Crisis. The point is that the markets were shocked upon realizing that there would be no government bailout of Lehman, and this triggered a global credit freeze which, in turn, contributed to a worldwide financial crisis.

46 The G20's direct involvement in attempts to stabilize the global economy began with the group's DECLARATION SUMmit ON FinANCIAL MARKETS AND THE WORLD ECONOMY (Washington, DC Nov. 15, 2008), https://www.g20.org/sites/default/files/g20_resources/library/Washington_Declaration.pdf. This declaration has been followed by a series of communiqués based on the work of the FSB and BCBS.
} 
So the need for global governance has become greater than ever, just as global governance itself has been weakening.

Let us consider why this is happening. Two closely related developments seem dominant, the subtle nuances of which are sometimes missed even where their verbiage has become commonplace. First, the technological revolution, particularly in communications, has facilitated seamless business activity across the globe. Second, there has been a massive and corresponding surge in global corporate (and not merely economic) activity that has become possible as a result of technology and that has transformed global business from the international to the seamlessly global.

Accompanying this business transformation has been the emergence-also facilitated by the technology revolution - of truly global finance. As has often times perversely been the case, the flag has followed business, instead of the other way around. Because business is now really global, the "flag" has itself had to be everywhere simultaneously, and the only way sovereigns can meet this demand is through the process of coordination, contestation and reliance upon multi-leveled domestic implementation that Professor Zaring describes in his defense of soft law as public international law. ${ }^{47}$

Global Technology

The world has experienced numerous technological revolutions. ${ }^{48}$ So there is nothing historically unique about the one we have been experiencing for the past twenty-five years. The current revolution, however, has had a dramatic impact on the nature of modern business and, particularly, on its conduct and operations. The logistics of "big box" stores, such as those operated by Walmart and the airlines, as examples, can be managed more centrally than ever before because of real time connectivity enabled by communications technology. Even more so has this been the case with the accompanying finance necessary to fund such businesses. ${ }^{49}$

\footnotetext{
47 See Zaring, supra note 39.

48 Carlota Perez, Technological Revolutions And Financial Capital: The Dynamics of Bubbles and GOLDEN AGES (2002).

49 See, e.g., Jane K. Winn, Catalytic Impact of Infromtatin Technology on the New International Financial Architecture, 34 INT'L LAWYER 137 (2000).
} 
Finance flows freely and almost instantaneously across vast global networks without the need to stop or even pause at national borders. Furthermore, largescale financiers have made no secret of their belief that the Walmart global model is one that will be followed by large financial institutions as well.50

This technological integration is itself not an unmitigated good. With connectivity comes also contagion, with technologically-based business comes technological dependency, and with technological dependency comes technologically-driven vulnerability. These dependencies can sometimes have dangerous consequences, not only for banks and their customers but even for international relations between states. ${ }^{51}$ Yet it is a world in which we now find ourselves and it is one to which public international law must itself adjust.

\section{Global Business and Finance}

The nature of the change is subtle but important. By "global" I do not merely mean that cross border activities require intense multi-state or "international" cooperation; it goes far deeper than this. Until relatively recently international trade and finance was largely a bilateral and modular affair between separate organizations exporting to each other or providing correspondent services as agents of each other, and operating through separate and locally incorporated subsidiaries, businesses. Now financial institutions are able to operate as if there are no borders or corporate segments at all.

\footnotetext{
${ }^{50}$ Mr. Dimon, Chairman and CEO of JP Morgan Chase \& Co., for example, has been quite clear on this point. See, e.g., Gabriel Sherman, The End of Wall Street As They Knew It, N.Y. MAG. (Feb. 5, 2012), http://nymag.com/news/features/wall-street-2012-2/ (quoting Mr. Dimon as saying that "companies big and small will still need underwriting, credit, capital management, and advice. McKinsey did a report that showed that the credit needs of multinationals are going to double in the next ten years," .... The net worth of the world is going to double in the next decade. Institutional funding will double in the next ten years. We're a store, you can buy bonds, FX, advice-we provide great products at a great price. That store is not going to go away. If you're a big, smart investor and we can give you the best price and the best service, you'll still be coming here, just like Wal-Mart and Costco"). Mr. Dimon has asserted this position on other occasions as well, and many top financiers share his views.

${ }^{51}$ Consequences currently reflected in "flash crashes" on trading exchanges, international concerns about the fairness and safety of high frequency trading, major systems outages for large banks, and the vulnerability of banking networks to international, sometimes state-sponsored, cyberattacks.
} 
This development has had a profound impact on business operations. It has enabled businesses and financial institutions to become truly "global" and not just "international" in their operations. Banks are able to institute seamless corporate operations through the medium of branches instead of subsidiaries, and they have indeed lobbied for and secured the right to do so in many if not most jurisdictions. The result is that when JP Morgan Chase \& Co. (JPM), for example, operates a branch in London, this branch is a direct and undifferentiated presence of JPM's bank in New York..$^{52}$

There are obvious advantages for the efficiency of business operations, yet these advantages are often accepted without an understanding of the disadvantageous implications. For example, one of the most visible consequences of seamless globalization has been the tight interconnectedness, particularly in finance, of business operations. Because there are fewer "firewalls" in the form of corporate legal entity separations, the contagion triggered by one company as it finds itself in difficulties can quickly spread across borders and, in the case of finance, across to other firms. ${ }^{53}$

Because of these factors, large financial firms do not think in terms of national jurisdictions at all, except when obliged to by the law. They organize their lines of business along functional and market lines, and these lines do not follow national boundaries. They are explicit about this, commonly using the term "global" as part of the title of the particular business division concerned and organizing that

\footnotetext{
52 Global banks tend to prefer using branches instead of subsidiaries if so allowed by host state law. This enables them to deploy capital across the whole branch network instead of having to meet capital requirements on a subsidiary-by-subsidiary basis, and it greatly facilitates and reduces the cost of operations because branch structures permit platforms to be used on a seamless basis across the branch network. Multiple legal entities subject to a variety of host state laws also require much more complex coding for shared platforms that might be deployed to support them. The bank structure is even more attractive to many British and European banks, where the bank (as opposed to holding company) tends to be the primary corporate unit in the overall conglomerate structure. ${ }^{53}$ Ironically, this form of globalization has brought us full circle to an earlier age of globalization, one in which merchant ships sailed the seven seas. While the connectivity such merchant shipping presented was much slower than that provided by the near-real-time networks of today, the effect of global shipping was to create forerunners for modern international financial regulation and public international law in the form of then-novel concepts such as flags of state and flags of conveniencein turn fragments of state sovereignty entering each other's spheres of jurisdiction with the necessity of mutual compromise and the development of the law of admiralty.
} 
way, ${ }^{54}$ and acknowledging their "global citizenship." 55 The consulting firms, which have a major influence on corporate strategy, urge large financial firms to address the issues from a global perspective, and analyze the challenges associated with global business from that perspective. ${ }^{56}$ In the rhetoric of one of the leading proponents of these developments, multinational enterprises are giving way to globally integrated organizations (GIEs). ${ }^{57}$ Bank thought leaders share this perspective. ${ }^{58}$ And we have yet to figure out the relationship between these development and the responsibilities of vast global organizations that might profess "global citizenship" yet not really fit within any established legal framework. ${ }^{59}$

Less noticed but equally important is a subtle difference between global capital markets and global banking markets that intensifies the "global" perspective even when national or domestic markets remain important. Because of the availability of seamless communications and the great increase in capital mobility resulting from financial liberalization across many of the world's economies, the ability to raise capital across borders is increasingly enticing. In theory, it seems that global capital markets optimize globally, meaning that the most efficient

\footnotetext{
${ }^{54}$ See, e.g., Deutsche Bank: http://www.gtb.db.com ("Global Transaction Services"). Deutsche Bank, in common with its peers, also emphasizes its "global network:" https://www.db.com/en/content/company/Global-Network.htm. ${ }_{55}$ See, e.g., Citigroup: http://www.citigroup.com/citi/about/global_citizenship.html ("global citizenship").

${ }^{56}$ Analyses by the major consulting forms are replete with references to the overwhelming dominance of globalization as an organizing principle. See the many reports produced by McKinsey's Global Institute, at http://www.mckinsey.com/insights/mgi; IBM Global, at http://www935.ibm.com/services/us/gbs/consulting/; . McKinsey refers to the "global grid," which it says must be built into every company because "every company is now a global company:" http://www.mckinsey.com/insights/innovation/the_global_grid. See also EY, TransForming BANKS, REDEFINING BANKING: GLOBAL BANKING OUTLOOK 2014-15 (2014), downloadable at http://www.ey.com/GL/en/Industries/Financial-Services/Banking---CapitalMarkets/Transforming-banks---redefining-banking (last visited July 13, 2014).

57 Samuel J. Palmisano, Re-Think: A Path to the Future (2014). Mr. Palmisano is the former CEO of IBM and Director of the Center for Global Enterprise (http://thecge.net). See also, e.g., Sam Palmisano, A new model for going global, CNBC COMMENTARY Apr. 1, 2014, available at http://www.cnbc.com/id/101544248; Samuel Palmisano, How multinationals have been superseded, Fin. TIMES June 11, 2006, http://www.ft.com/intl/cms/s/1/c9fad85e-f96a-11da-8ced0000779e2340.html\#axzz2yU8psmw5

${ }^{58}$ See e.g., Allan D. Grody \& Peter J. Hughes, Modern Banking is a Global Enterprise, AM. BANKER, Apr. 7, 2014, available at http://www.americanbanker.com/bankthink/modern-banking-is-a-globalenterprise-1066717-1.html.

59 The literature on this subject is growing rapidly. For an extended discussion, see, e.g., GRAHAME F.

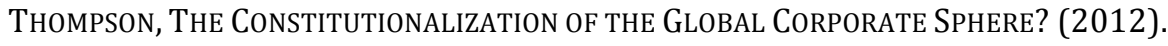


allocation of capital will come from a seamless global framework. It is therefore not surprising that the policy direction of capital markets organizations such as the International Organization of Securities Companies (IOSCO) is strongly toward further liberalization across borders and towards a truly global capital market and a global institutional framework. ${ }^{60}$

\section{Consequences for Global Governance}

\section{National Concerns_-An Added Dimension of Complexity}

On the other hand, however, it is not at all clear that banking markets and their supervision optimize globally. Precisely because of the quasi-governmental functions performed by banks and the local sources of their funding and political support, ${ }^{61}$ it might well be that global banking regulation, as distinct from banking operations and concomitant political action, optimizes locally. If this is correct, it is likely that the process described by Professor Zaring will become more complicated and intense than ever. The "soft law" architecture and processes of the New Financial Architecture might even, paradoxically, become a model for $21^{\text {st }}$ Century public international law itself. Certainly, the pressure for continuing negotiation toward a legal and regulatory regime that facilitates the growth of global business and finance is unlikely to stop, as is the demand for systems for resolving transnational business failures.

Balkanization

Progress toward coherent global reform has been faltering. In some respects, national reactions to global efforts have actually produced greater Balkanization. In the United States, egged on by the banks themselves, prominent legislators have

\footnotetext{
60 This is a theme expressed by many global financiers and it has been nicely summed up in a speech by the Secretary General of IOSCO. See Remarks by David Wright, Secretary General of IOSCO, to The Atlantic Council, Washington, DC 10 December 2012, available at http://www.iosco.org/library/speeches/pdf/20121210-Wright-David.pdf.

61 Lawrence G. Baxter, Betting Big: Value, Caution and Accountability in an Era of Large Banks and Complex Finance, 31 REV. BANKING \& FIN. L. 765 (2011-12), at 818-25.
} 
even attempted to prevent the implementation of Basel III-based reforms. ${ }^{62}$ At the same time, US regulators have imposed even more severe constraints on foreign banking organizations (FBOs), leading to complaints in other countries, particularly within the European Union. The European Banking Union-one of the signature efforts to address the implications of widespread systemic risk across borders-has been met with considerable hostility in the United Kingdom, including threats to withdraw. More broadly, the European Union and the United States have found that they might have to exclude financial services from what would otherwise become the broadest regional trade treaty ever developed. ${ }^{63}$ Other nations have also baulked at efforts to impose global standards, what has even been described as a "new colonialism," 64 indicating broad resistance to any trend toward global harmonization.

The Atlantic Council has addressed the tendency toward Balkanization and divergence in a pair of reports published in 2010,65 and 2013.66 These reports, focusing on developments primarily in Europe and the United States following what was, to some extent, a "North Atlantic Crisis," 67 noted not only the obstacles to US and European harmonization but also the fact that Asian interests are themselves

\footnotetext{
62 See, e.g., the bill introduced by Senators Sherrod Brown (D-Ohio) and David Vitter (R-LA) that would prohibit any further implementation of Basel III: Terminating Bailouts for Taxpayer Fairness Act of 2013, S. _, § 3(e). The Bill was introduced as an amendment (Vitter Amdt. No. 689) and voted up overwhelmingly in a protest vote on http://www.senate.gov/legislative/LIS/roll_call_lists/roll_call_vote_cfm.cfm?congress=113\&session $=1 \&$ vote $=00070$, then quietly dropped by the Senate leadership. See Shahlen Nasiripour \& Michael McAuliff, With The Lights On, 99 Senators Voted Against Wall Street. The Lights Went Off And They All Fled, Huff. Post Dec. 17, 2013, http://www.huffingtonpost.com/2013/12/17/budget-deal-2013megabanks_n_4462305.html (updated Jan. 23, 2014).

${ }^{63}$ Shawn Donnan, EU threatens to cut financial services from trade deal, Fin. TIMES, June 13, 2014 (reporting on the Transatlantic Trade and Investment Partnership currently being negotiated between the EU and US).

${ }^{64}$ Ross Buckley, The Changing Nature of Banking and Why it Matters, ch. 1 supra.

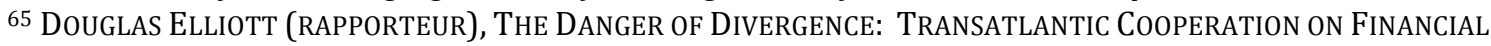
REFORM (2010), http://www.atlanticcouncil.org/publications/reports/the-danger-of-divergencetransatlantic-cooperation-on-financial-reform.

${ }^{66}$ Chris Brummer (RAPporteur), The Danger of Divergence: Transatlantic Financial Reform \& The G20 AGENDA (2013), http://www.atlanticcouncil.org/publications/reports/the-danger-ofdivergence-transatlantic-financial-reform-the-g20-agenda.

67 A possibility raised in its summary of the 2010 report, Atlantic Council, The Danger of Divergence: Transatlantic Cooperation on Financial Reform, Oct. 6, 2010, at http://www.atlanticcouncil.org/publications/reports/the-danger-of-divergence-transatlanticcooperation-on-financial-reform.
} 
quite different. ${ }^{68}$ As the CEO of the Hong Kong Securities and Futures Commission noted at a follow up conference, "transatlantic ... preferences differ considerably from that of the Asian market, which continues to focus on its underdeveloped capital market, problems with SME funding, a general lending gap and infrastructure." 69

Feeding the Global Maw

Fears once expressed about global corporations becoming larger, more powerful, and more relevant to people's lives are now a truly awesome reality"awesome" in the strictest sense of the word. What Hong Kong Shanghai Bank (HSBC) does in London is tightly connected, and often an integral element of, what HSBC is doing in New York or Hong Kong or Shanghai. We have seen some of the consequences recently in the fines imposed on global banks headquartered in other countries for violating New York and US wire transfer laws. ${ }^{70}$ So it seems likely that various aspects of public international law will be drawn into areas of controversy and misfeasance driven by the presence of global business operations.

The impact on the methodology and processes of public international law is likely equally profound: in following business, the flag (i.e., sovereign states) have had no choice but to "negotiate" mutually acceptable standards and deference to each other, while acknowledging the power of "home state" rules within their "host

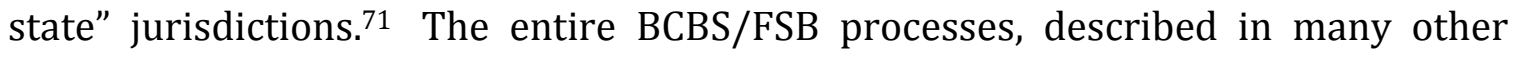
chapters in this book, ${ }^{72}$ as well as the history of European integration, are illustrations of this change. Chris Brummer has described the emergence of a new

${ }^{68}$ See further Xi Chao, The Role of Emerging Economies in the Evolution of International Banking Regulation in the Post-GFC World, infra ch. 8.

${ }^{69}$ Quoted in a summary of the conference, Atlantic Council, The Danger of Divergence: Discussion of Brussels, EU Reforms at the European Parliament, Feb. 12, 2014, available at http://www.atlanticcouncil.org/events/past-events/the-danger-of-divergence-ttip-and-theimportance-of-a-global-perspective.

70 Well-publicized examples in the financial world are the settlements by British, French and Swiss banks for violations of US wire transfer laws aimed at enforcing sanctions against Iran, combating drug laundering and tax evasion. The most recent examples are the fines levied by the US against HSBC and BNP Paribas.

${ }^{71}$ These assumptions were the basis for the first major agreement on principles of global bank supervision, namely the Basel Concordat.

${ }^{72}$ See, for example, chapters $4, \ldots$, and _. 
form of "minilateralism," in which a conglomeration of discreet bilateral alliances, together with the veneer of "soft law, sometimes concerted central bank actions"73 and other forms of 'financial engineering' are supplanting the vision of multilateralism and global harmony. ${ }^{74}$

\section{Global Autonomy}

Let us examine some of these developments as they proceed directly from financial globalization. First, the sheer power of global banks has enabled them to create a partially autonomous, "self governing" world of financialization, most particularly in the world of derivatives. While recent reform efforts in the United States and Europe have attempted to move swaps derivatives to regulated exchanges, earlier deregulation enabled the growth of a vast industry of over the counter (OTC) derivatives that still comprise the vast proportion of derivatives transactions and risk exposures in the global economy. ${ }^{75}$ OTC business is largely conducted according to the rules of the International Swaps and Derivatives Association (ISDA), ${ }^{76}$ an entirely industry-based, non-governmental organization that tends to favor the progressive global unification of derivatives rules under industry governance. ${ }^{77}$ This preference, opaque and accessible only to members of ISDA-the worlds largest financial firms-is promoted by ISDA members and shows little prospect of becoming incorporated into recognizable government forms of regulation. ${ }^{78}$

\footnotetext{
${ }^{73}$ For an extended discussions of the extensive powers of central bankers, see, e.g., NEIL IRWIN, THE

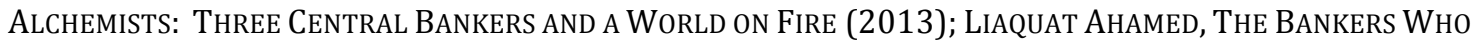
BROKE THE WORLD (2009).

${ }^{74}$ Chris Brummer, Minilateralism: How Trade Alliances, Soft LaW, And Financial EngineERing Are REDEFINING ECONOMIC STATECRAFT (2014).

75 While the risk exposure has reduced somewhat, perhaps because of reforms requiring the use of exchanges for swaps, the notional amounts of OTC derivatives contracts, including credit default swaps, is running in the $\$ 600$ to over $\$ 700$ trillion range. See BANK FOR InTERNATIONAL SETTLEMENTS, QUARTERLY REVIEW (March 2014) at A10, available at http://www.bis.org/publ/qtrpdf/r_qs1403.pdf. ${ }^{76} \mathrm{http}: / /$ www2.isda.org.

77 See, e.g. ISDA DERIVITIVIEWS, Jan. 29, 2014, http://isda.derivativiews.org/2014/01/29/marketfragmentation-is-becoming-a-reality/.

78 See also Tim Büthe \& Walter MatTli, The New Global Rulers: The Privatization of Regulation in THE WORLD ECONOMY 32 (2011).
} 
Financial Center Competition

Secondly, the world's largest financial centers display a continuing interest in attracting and keeping as much financial business as possible. ${ }^{79}$ Specific market centers actively collaborate with global firms to achieve this ambition, and this market-based collaboration, like the earlier offshore financial centers and unlike traditional sovereign action that was at least politically accountable in some sense, serves to promote further opportunities for regulatory arbitrage that run counter to the aspirations of the G20 for a more coordinated world of financial governance. ${ }^{80}$

\section{New Tentacles of Sovereign Power}

Running in a different direction, yet just as much the product of financial globalization, certain sovereigns have acquired enormous-some would say disproportionate-power as a result of the globalization of financial networks. In the United States, for example, the United States Treasury, and even the State of New York have been able to use the criticality of the payments system to impose very substantial sanctions on banks around the world when such firms have not complied with US anti-money-laundering (AML) and tax evasion laws and even in situations in which these firms have not conducted the offending transactions within the United States itself. ${ }^{81}$ Such power has even led other major banking nations to force changes to their own, long-standing banking laws. ${ }^{82}$ Whether the objectives and results are good or bad is beside the point: the fact is that certain financial markets now provide a fulcrum for certain sovereigns to exercise

\footnotetext{
79 One of the classic expressions of this market ambition is the recent speech by Mark Carney, Governor of the Bank of England, declaring that "we [meaning London] are open for business." Mark Carney, The UK at the heart of a renewed globalisation (speech given at an event to celebrate the $125^{\text {th }}$ anniversary of the FINANCIAL TIMES, London Oct. 24, 2013), http://www.bankofengland.co.uk/publications/Documents/speeches/2013/speech690.pdf. ${ }^{80}$ Cross reference to discussion in Dirk Zetzsche, Reconceptualising the Regulation of International Financial Centers, infra ch. 23 (will add and modify if this turns out to be a helpful cross reference).

81 See Juan C. Zarate, Treasury's War: The Unleashing OF a NeW Era of Financial Warfare (2013).

${ }^{82}$ Under pressure from the United States, Switzerland has substantially amended its bank secrecy laws. The Swiss Foreign Account Tax Compliance Act was brought into force by the Swiss Federal Council on June 30, 2014.
} 
substantial "extra-territorial" power, ${ }^{83}$ a development almost certain to invite retaliation by other centers and further Balkanization of global governance. French and European officials, for example, like their British counterparts earlier, ${ }^{84}$ have expressed outrage at the huge US fines ( $\$ 8-10$ billion or more) that were sought and ultimately applied against BNP Paribas, ${ }^{85}$ as well as the continuing possibility of further huge fines relating to rate-setting impropriety. ${ }^{86}$

\section{Banks Versus the State}

Against this backdrop, the chase for yield that is driving global financial firms is also leading to global/domestic conflict. Just as the delays or failures in global financial reform have generated domestic pressures for national solutions, so too has the urgency to maintain financial yield within the big banks led such banks to

\footnotetext{
83 European derivatives regulation is also likely to have extensive extraterritorial effect. See the review by Alexandria Carr, The Extraterritorial Effect of the EU Regulation of OTC Derivatives, HARV. L. SCH. FOR. CORP. GOV. \& Fin. REG., June 14, 2014, http://blogs.law.harvard.edu/corpgov/2014/06/14/the-extraterritorial-effect-of-the-eu-regulationof-otc-derivatives-2/.

${ }^{84}$ Fines imposed by US regulators on the London-headquartered Barclays, HSBC and Standard Chartered Bank, for violations of US anti-money-laundering regulations led to angry reactions and charges of ulterior motives in Britain and tensions between US and British regulators. See, e.g., Standard Chartered: Boris accuses US regulators of being "motivated by jealousy," TELEGRAPH, Aug. 9, 2012, http://www.telegraph.co.uk/finance/newsbysector/banksandfinance/9462...ered-Borisaccuses-US-regulators-of-being-motivated-by-jealousy-html; Walter Ellis, America is turning on British banks in order to protect Wall Street, TELEGRAPH BLOGS, Aug. 8, 2012, http://blogs.telegraph.co.uk/news/walterellis/100175525/america-is-turning-on-british-banks-inorder-to-protect-wall-street/; Jim Pickard, British MPs accuse US of anti-City agenda, Fin. Times, Aug. 7, 2012, http://www.ft.com/intl/cms/s/0/4425bcea-e0b2-11e1-8d0f-00144feab49a.html?; Tom Burgis \& Patrick Jenkins, King questions StanChart probe, Fin. TIMES, Aug. 8, 2012, http://www.ft.com/intl/cms/s/0/2ce700dc-e145-11e1-839a-00144feab49a.html; Dana Cimilluca \& Victoria McGrane, Trans-Atlantic Tensions Increase, WALL ST. J., Aug. 13, 2012, http://professional.wsj.com/article/SB100008723963904440427045775...992700.html?. One British banker was quoted in documents as saying, "who are you tell us, the rest of the world, that we're not going to deal with Iranians."

85 BNP Paribas was ultimately fined $\$ 8.9$ billion and subjected to a number of other restrictions and sanctions. For a recap, see, e.g., Jessica Silver Greenberg \& Ben Protess, Grieving Father Pulls a Thread That Unravels BNP's Illegal Deals, N.Y. Times Dealb\%k, Jun. 30, 2014, at http://dealbook.nytimes.com/2014/06/30/a-grieving-father-pulls-a-thread-that-unravels-illegalbank-deals/.

86 See, e.g., Noémie Bisserbe \& David Enrich, ECB Officials Anxious About Impact of U.S. Fines on E.U. Banks, WALL ST. J. June 3, 2014, http://online.wsj.com/articles/ecb-officials-anxious-about-impact-ofu-s-fines-on-eu-banks-1401798968; Michael Stothard, France slams US over possible \$10bn-plus fine against BNP Paribas, Fin. TIMES, June 3, 2014, http://www.ft.com/intl/cms/s/0/9a8e516c-eafd-11e39c8b-00144feabdc0.html?\#axzz33atKaZwS; Ben Protess \& Jessica Silver-Greenberg, French Officials Twist U.S. Arms in Bank Inquiry, N.Y. TIMES DEALB\%K, June 2, 2014, http://dealbook.nytimes.com/2014/06/02/french-officials-twist-u-s-arms-in-bank-inquiry/.
} 
consider, and in some cases even implement, evasive action to avoid national restrictions. Deutsche Bank and Barclays both attempted, with partial success, to restructure in order to avoid the new requirements of the US Dodd-Frank Act. ${ }^{87}$ More recently, the Royal Bank of Scotland has restructured its US operations in order to avoid the new US Intermediate Holding Company requirements for foreign banking organizations. Such actions will create advantages and disadvantages across the global competitive stage rather than an "even playing field;" and will thus possibly lead to retaliatory actions by other national jurisdictions, thereby further distancing the vision of global governance.

Nor has the reaction been confined to countries other than the United States. In the United States there has been a significant element of hostility toward international efforts at coordination. One bill introduced into Congress by a liberal Democrat and a conservative Republican would actually prohibit the further implementation of Basel III in the US. ${ }^{88}$ No doubt some of this hostility has been encouraged by US banks that are opposed to standards thought to be unnecessary or unfair. 89 That global banks, for which one might imagine a set of uniform or harmonized global rules would actually be convenient, would oppose such a development demonstrates the enormous domestic political and even cultural obstacles to further global coordination.

These, and many other factors, not least the use by states of financial networks as a means of implementing their policies on matters such as sanctions and tax evasion, suggest that bank/state configurations are making prognostication on the impact of globalization on financial markets murkier than ever..$^{90}$

\footnotetext{
${ }^{87}$ See David Enrich \& Laura Stevens, Deutsche Avoids Dodd-Frank Rule, WaLl ST. J., Mar. 22, 2012, http://online.wsj.com/news/articles/SB10001424052702303812904577295614224666918; Tom Braithwaite \& Shahien Nasiripour, Deutsche Bank avoids US capital rules, Fin. TIMES, Mar. 21, 2012, http://www.ft.com/intl/cms/s/0/f2d96462-738e-11e1-94ba-00144feab49a.html.

${ }^{88}$ See supra note 62.

${ }^{89}$ Some US bank executives have railed against the complexity and severity of Basel III, even though, ironically, even stricter rules have ultimately been implemented within the US. This in turn has led to protests by foreign banks and their supporting governments.

${ }^{90}$ I have developed some of the more recent themes in a working paper, tentatively titled Extraterritorial Impacts of Recent Financial Regulation Reforms: A Complex World of Global Finance (2014), available at http://scholarship.law.duke.edu/faculty_scholarship/3355/.
} 
International Solutions?

One example where traditional public international law techniques are manifestly inadequate for the modern global economy is the use of treaties to address global financial instability. Observers steeped in the orthodoxy of PIL have proposed that we should create a World Financial Organization (WFO) along the lines of the World Trade Organization (WTO), ${ }^{91}$ yet this suggestion seems quaintly out of touch with modern political reality. ${ }^{92}$ So too, must it be said of the very thoughtful, treaty-based solution of a global banking regulator recently developed and refined most prominently by Emilios Avgouleas, ${ }^{93}$ a cumbersome and laborious model unlikely to meet the needs of politically responsive regulation in a rapidly moving global marketplace. ${ }^{94}$

\section{Conclusion}

International financial regulation in a multi-polar, multi-lateral world was difficult enough. Yet in that framework, nations could at least coordinate the regulation of their financial institutions on a reciprocal basis, and financial firms were not so globally encompassing as to find cross-border restrictions a serious impediment to their operations and profitability. These circumstances have all changed. "International" has morphed into "global," and global finance implies omnipresence, with borders being irrelevant to business operations, strategy, deployment of capital and management. Global firms are competing head-to-head with each other,

\footnotetext{
${ }^{91}$ See, e.g., Barry Eichengreen, Not a New Bretton Woods But a New Bretton Woods Process, in What G20 LEADERS Must Do To Stabilize OUR EConomy AND FiX THE FinANCIAL SYSTEM (Barry Eichengreen \& Richard Baldwin eds 2008) 25, available at http://www.voxeu. org/reports/G20_summit.pdf; Peter Boone and Simon Johnson, Will the Politics of Global Moral Hazard Sink Us Again?, in ThE Future OF FinANCE (Adair Turner et al 2010) 247 at 269. For some historical context see, e.g, HEIDI MANDANIS Schooner and Michael W. Taylor, Global Banking Regulation: Principles and Policies (2010) at 29294.

92 See further, e.g., Lawrence G. Baxter, Exploring the WFO Option for Global Banking Regulation, in GLOBALIZATION AND GOVERNANCE (Laurence Boulle ed. 2011) 113-24; BRUMMER, supra note 38, at 26971.

93 See AvgoulEAS, supra note 38, ch. 8.

${ }^{94}$ This inability to move very quickly is perhaps a basic problem of the Banking Union in Europe.
} 
irrespective of their "national" origins. To use Professor Schweller's imagery, we have entered an "age of entropy." 95

At the same time, the plight of any one of these firms can have a simultaneous impact on many, if not all of the others. When any one of these behemoths is larger, in terms of global assets, than the entire GDP of many large individual nations, the collapse of one firm can constitute a severe threat to the financial system of any or all nations. Global financial firms have joined their global industrial counterparts to wield extraordinary power over economies and political frameworks. ${ }^{96}$

We demand that such systemic, even existential, risk be contained through regulation. But can we say that we are closer to meaningful global regulation than we were before 2008? Until the bankruptcy of a global firm can be credibly resolved across borders, it seems fatuous to claim that we are. Notwithstanding assurances from some national regulators, the global orderly resolution framework remains little more than a theoretical regime. ${ }^{97}$ With the renewal of domestic reactions against foreign measures, it would appear that we are indeed further away from a meaningful global regulatory system than ever.

To the extent that the purveyors of global finance are unlikely to withdraw to their national bases, to the extent that financialization has taken such deep root that it is unimaginable that it might shrink to more manageable levels, and to the extent that the thirst of developing economies for ever-greater inflows of capital will probably not diminish, it is likely that the hiatus between global finance and matching global regulation will remain, if not grow deeper.

\footnotetext{
95 Randall L. Schweller, The Age of Entropy: Why the New World Order Won't be Orderly, For. AFFAIRS, Jun. 16, 2014, http://www.foreignaffairs.com/articles/141568/randall-l-schweller/the-age-ofentropy?.

96 Professor Wilks aptly describes how corporations acquire greatly enhanced political power by

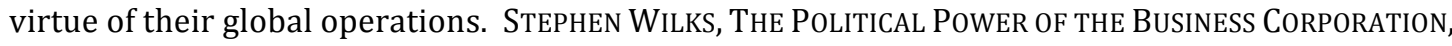
esp. ch. 3 (2013). See also the discussions in THOMPSON, supra note 59; THE NEW GLOBAL RuLERS, supra note 78 .

${ }^{97}$ As one leading expert has put it, notwithstanding all the work already done by US, British and European regulators, "cross-border resolution without government intervention [i.e. some kind of bailout] is still at best uncertain for banks and wholly unaddressed for nonbanks." What it Takes for the FDIC SPOE Resolution Proposal to Work, HARV. L. SCH. For. CoRP. Gov. \& Fin. REG., Apr. 5, 2014, http://blogs.law.harvard.edu/corpgov/2014/04/05/what-it-takes-for-the-fdic-spoe-resolutionproposal-to-work/. Compare, Daniel Indiviglio, A Hurdle to Winding Down a Failing Global Bank, N.Y. TiMES DEALB\%K, Nov. 18, 2013, http://dealbook.nytimes.com/2013/11/18/a-hurdle-to-windingdown-a-failing-global-bank/?_php=true\&_type=blogs\&_r=0.
} 
Where does this leave us? Will we be driven out of desperation to muster the resolve to create a World Finance Organization through a global treaty? Will we instead see deeper national trenches that restrict global finance and trigger thunder flashes of extraterritorial retaliation? Will we see more efforts at financial freedom like those to which some sponsors of Bitcoin aspire?98 ${ }^{98}$ These are the challenges forming the agenda for reconceptualizing global finance, challenges that will not lessen but only grow more intense while we await the next financial crisis.

\footnotetext{
${ }_{98}$ Bitcoin as a means of securing freedom from government-controlled money is a dream among many Bitcoin supporters. See, e.g., Blog, Crypto-Anarchy and Libertarian Entrepreneurship-Chapter 3: The Killer App of Liberty, THE MISES CIRCLE, http://themisescircle.org/blog/2013/05/29/cryptoanarchy-and-libertarian-entrepreneurship-chapter-iii/.
} 